\title{
Author Correction: The Positivity Imperative in Youth Education as a Form of Cruel Optimism
}

\author{
Kristiina Brunila $^{1} \cdot$ Saara Vainio $^{1} \cdot$ Sanna Toiviainen ${ }^{1,2}$
}

Published online: 11 February 2022

(C) The Author(s) 2022

\section{Author Correction: Journal of Applied Youth Studies (2021) 4:313-327 https://doi.org/10.1007/s43151-021-00047-3}

The correct affiliation for Sanna Toiviainen is University of South-Eastern Norway, Drammen, Norway.

The original article has been corrected.

Open Access This article is licensed under a Creative Commons Attribution 4.0 International License, which permits use, sharing, adaptation, distribution and reproduction in any medium or format, as long as you give appropriate credit to the original author(s) and the source, provide a link to the Creative Commons licence, and indicate if changes were made. The images or other third party material in this article are included in the article's Creative Commons licence, unless indicated otherwise in a credit line to the material. If material is not included in the article's Creative Commons licence and your intended use is not permitted by statutory regulation or exceeds the permitted use, you will need to obtain permission directly from the copyright holder. To view a copy of this licence, visit http://creativecommons.org/ licenses/by/4.0/.

The original article can be found online at https://doi.org/10.1007/s43151-021-00047-3.

Kristiina Brunila

Kristiina.brunila@helsinki.fi

1 AGORA for the Study of Social Justice and Equality in Education-Research Centre, University of Helsinki, Helsinki, Finland

2 Western Norway University of Applied Sciences, Bergen, Norway 